\title{
EVIDENCE FOR THE INSULIN-DIRECTED SPECIFICITY OF RABBIT ANTI-INSULIN SERUM ${ }^{1}$
}

\author{
By EDWARD R. ARQUILLA AND ABRAM B. STAVITSKY 2 \\ (From the Departments of Anatomy and Microbiology, School of Medicine, Western Reserve \\ University, Cleveland, 0 .)
}

(Submitted for publication October 31, 1955; accepted December 28, 1955)

In the previous paper (2) a method was described for the immunological assay of microgram quantities of insulin. This method employed the reaction between rabbit antiserum to insulin and sheep erythrocytes conjugated with insulin. However, the applicability of the method to the measurement of insulin is obviously dependent upon the insulin-directed specificity of the antiserum which is employed in the assay. Therefore, the present experiments were designed to determine the specificity of rabbit antisera to crystalline beef insulin. In order to establish this specificity answers were sought to these questions: 1 ) To what extent will the insulin antisera react with contaminants that may be present in the crystalline beef insulin used for immunization? 2) Will these antisera react with proteins derived from beef plasma and other sources? 3) To what extent will the antisera to beef insulin react with insulin from other species? 4) Will the antisera interfere with the physiological action of insulin?

Previous investigators have provided much information on some of these points. Lewis (3) and Barral and Roux (4) have shown that purified insulin is a different antigen from those in serum or crude extracts of pancreas. The immunological similarity of insulin prepared from several species has been demonstrated by Lewis (3) and also by Wasserman and Mirsky (5). Using the SchultzDale technique, Lewis (3) showed that guinea pigs can be sensitized with insulin from one species and shocked with insulin from another species. Wasserman and Mirsky (5) confirmed this in sensitization and complement fixation experiments. However, these experiments were qualitative in nature. Furthermore, the insulin preparations

1 This study was supported in part by a grant from the Eli Lilly Co. A preliminary report of this work was presented before the American Association of Anatomists in Philadelphia in the Spring of 1955 (1).

2 This study was conducted in part during the tenure of an Established Investigatorship from the American Heart Association. employed were less pure than those used in the present study.

The ability of insulin antibodies to neutralize the physiological action of insulin has been demonstrated by Lowell (6), Banting, Franks, and Gairns (7) and Marsh and Haugaard (8). Recently, Moloney and Coval (9), using insulin neutralization techniques, have demonstrated the immunological similarity of crystalline insulin from several species. He was also able to produce diabetes in the mouse by the intravenous injection of guinea pig antiserum to insulin.

The present experiments were performed with rabbit insulin antisera. The hemolysis-inhibition method described in the previous paper (2) was employed in testing the specificity of these antisera, because this is the method which is proposed for the assay of insulin.

The evidence obtained indicates that these antisera are highly specific for insulin per se. The results also show that these antisera cross-react to a great extent with insulin from four species. Evidence for the interference of rabbit insulin antiserum with the physiological action of insulin in mice is also presented.

\section{MATERIALS AND METHODS}

\section{Antigens}

Crystalline beef insulin (lot No. 535664).8 This is a sample which contains 27 units per $\mathrm{mg}$. There is some hyperglycemic factor present in the preparation. This sample was used as the antigen in preparing the antisera (2).

Trypsinized crystalline beef insulin (lot No. 466368).8 This sample contains no hyperglycemic activity and assayed at 27 units per mg. It probably contains traces of trypsin.

Human insulin.4 This sample contained cresol as preservative and assayed at 11 units per $\mathrm{ml}$.

${ }^{8}$ We wish to thank the Eli Lilly Co. for the beef insulin samples, the bovine glucagon, and the crude extract of beef pancreas.

4 We wish to thank the Connaught Research Laboratories for the solution of human insulin. 
The " $A$ " components of sheep, pork, and beef insulin. Using the counter-current distribution technique Harfenist and Craig (10) have been able to separate supposedly homogeneous insulin samples into two components, $A$ and $B$, with distinctly different partition ratios. The material recovered from each peak was crystalline and both of about equal biological activity. The only difference between the $\mathrm{A}$ and $\mathrm{B}$ components is that the former contains six amide groups whereas the latter contains only five. These " $\mathrm{A}$ " components of sheep, beef, and pork insulin were prepared by Harfenist and Craig and graciously presented to us.

Crude extract of beef pancreas. ${ }^{3}$ This preparation was assayed by the mouse convulsion method and contained 0.5 units of insulin per mg. of dry weight.

Bovine glucagon. This is a highly purified preparation of crystalline glucagon (hyperglycemic factor).

Other proteins. Bovine gamma globulin lot No. C904 (Armour Co.) is fraction II of bovine plasma. Bovine albumin lot No. L11705 (Armour Co.) is fraction V of bovine plasma. Egg albumin lot No. E90115 (Armour Co.) is a 3 times recrystallized preparation. Human gamma globulin ${ }^{5}$ from plasma is fraction II, 1, 2, which was prepared by the Cohn method IX (11). Human serum albumin ${ }^{5}$ from plasma is fraction $V$ which was prepared by the Cohn method VI (12).

Insulin conjugated erythrocytes. The preparation of these cells, including the conjugating agent, bis-diazobenzidine, was described in the previous paper (2).

\section{Sera}

Rabbit sera were employed as a source of diluent for the antiserum as well as of antibodies to insulin and egg albumin. The insulin antisera were produced in adult white rabbits using alum-precipitated beef insulin (lot No. 535664), as described in the previous paper (2). The egg albumin antisera were prepared as previously described (13).

The preparation of absorbed guinea pig serum (source of complement). The sensitivity of the methods for the hemolysis titration of insulin antiserum and the hemolytic assay for insulin as described in the previous paper (2) was limited by the high background due to nonspecific hemolysis of the sheep erythrocytes by guinea pig serum. It was observed in our laboratories and independently by Brumfield and Ross (14) that guinea pig serum in high concentration causes hemolysis of either insulin-conjugated or non-conjugated sheep erythrocytes. For instance, about $0.06 \mathrm{ml}$. of pooled guinea pig serum is capable of causing complete hemolysis of $0.1 \mathrm{ml}$. of a 2 per cent suspension of nonsensitized sheep erythrocytes in a final volume of $0.6 \mathrm{ml}$. In order to avoid this nonspecific hemolysis the guinea pig serum used as the source of complement is absorbed with an equal volume of washed packed sheep erythrocytes for 1 hour at $10^{\circ} \mathrm{C}$.

5 We wish to thank Drs. Louis E. Pillemer and Irwin Lepow for the preparations of human gamma globulin and human serum albumin.
After absorption the complement titre decreases about 20 per cent probably because it is diluted during the absorption. The factor responsible for the nonspecific hemolysis is decreased from 16 units per $\mathrm{ml}$. ( $0.06 \mathrm{ml}$. guinea pig serum to $0.1 \mathrm{ml}$. erythrocytes) to less than 2 units per ml. Evidence indicating that this factor is properdin has been presented in another paper (15).

Titration of antiserum by hemolysis inhibition. In testing the specificity of the insulin antisera against various substances the method for the hemolytic titration of rabbit antiserum to insulin which has been described in the previous paper (2) was used. Serial dilutions of a given rabbit antiserum were prepared in $1 / 100$ normal rabbit serum. In the control serial dilutions, saline $(0.1 \mathrm{ml}$.) was preincubated with each dilution. In the experimental serial dilutions the test material in $0.1 \mathrm{ml}$. was preincubated with each dilution. The amount of hemolysis of the insulin conjugated erythrocytes at each dilution in the control set of serial dilutions was compared with the amount of hemolysis obtained in each dilution of the experimental sets of serial dilutions. In this way it was possible to determine to what extent any given protein or insulin sample reacted with the antiserum. The ability of the test protein or insulin to react with the rabbit antiserum to crystalline beef insulin was manifested by the extent to which hemolysis was inhibited.

The neutralization of insulin by rabbit antiserum in the mouse. The ability of mice to remain clinging to a wire mesh after they had been injected with insulin (lot No. 535664) which had been mixed with either rabbit antiserum or normal rabbit serum, was used to test the capability of antiserum to neutralize the insulin.

The mice were injected with $0.4 \mu \mathrm{g}$. of crystalline beef insulin per gram body weight, which was equivalent to 0.1 unit per gram body weight. The insulin was preincubated with either insulin antiserum or normal rabbit serum for more than 5 minutes but less than 15 minutes prior to injecting the mice with the mixture of serum and insulin. The preincubation mixture consisted of a ratio of $2 \mathrm{ml}$. of serum to $0.5 \mathrm{ml}$. of insulin solution containing 100 micrograms of insulin. One $\mathrm{ml}$. of this mixture was equivalent to 1.04 units of insulin. The mice were selected at random for the control and experimental group using a table of random numbers from Snedecor (16). The mice were injected intraperitoneally with 1 ml. (per 10 grams body weight) of the mixture containing either antiserum and insulin or normal rabbit serum and insulin. They were then placed on a $1 / 4$ inch wire mesh screen which was inclined at an angle of 70 degrees. The length of time they remained clinging to the screen was noted.

\section{RESULTS}

\section{Reactions between rabbit insulin antiserum and other pancreatic proteins}

Glucagon. Glucagon, which is a known contaminant of crystalline insulin preparations, was tested in two systems to determine whether in- 
hibition of hemolysis was associated with a specific reaction between glucagon and an antibody in the insulin antiserum. Egg albumin sensitized cells and rabbit egg albumin antiserum were employed in the control system. To insure the presence of sufficient antigen to react with antibody to glucagon in the insulin antiserum, hemolysis-inhibition by $100 \mu \mathrm{g}$. of beef glucagon was compared with that by $10 \mu \mathrm{g}$. of crystalline beef insulin.

Addition of glucagon caused the same small decrease of hemolysis in both the insulin and egg albumin systems as the addition of saline (Figure 1), indicating non-specific inhibition of hemolysis rather than a reaction of glucagon with antibody. On the other hand, $10 \mu \mathrm{g}$. of insulin were considerably more effective than $100 \mu \mathrm{g}$. of glucagon in specifically decreasing the hemolysis in the insulin system.

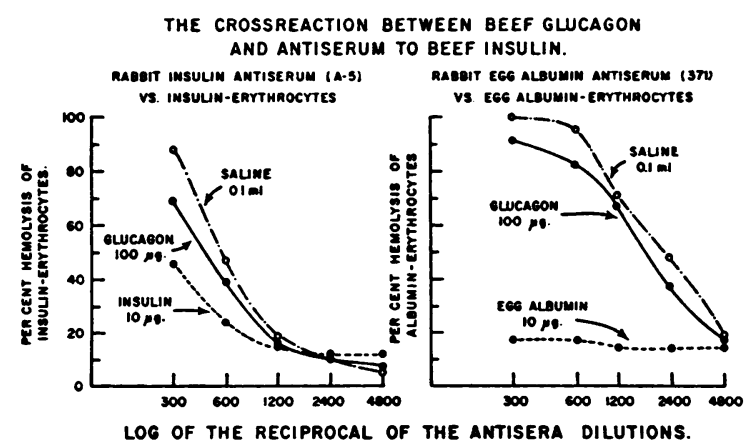

FigURe 1

Crude bovine pancreatic extract. If the rabbit insulin serum is indeed specific for insulin per se, it should react only with the insulin that is present in a crude fraction of pancreas. Therefore, the ability of $100 \mu \mathrm{g}$. of crude pancreatic extract (containing 0.5 units of insulin per mg. dry weight) to react with insulin antiserum, was compared with that of $1.8 \mu \mathrm{g}$. crystalline insulin containing an equivalent number of units. These calculations were based on the unitage of crystalline beef insulin (27 units per mg.).

The inhibition of hemolysis was comparable when either the crude pancreatic extract or the crystalline insulin was preincubated with the rabbit insulin antiserum (Figure 2). If contaminants of insulin had combined with the antiserum, inhibition of hemolysis by the pancreatic extract should have been much greater than that observed with

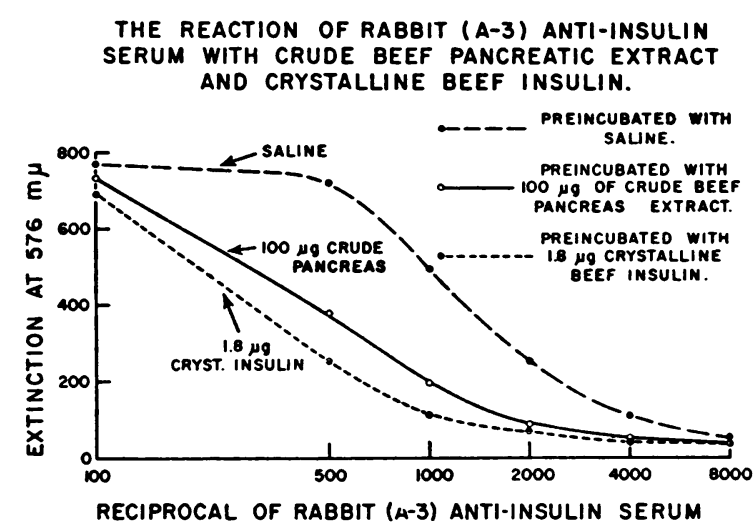

Figure 2

an equivalent number of units of crystalline insulin. Therefore, with this method antibodies to bovine pancreatic contaminants of insulin could not be detected in rabbit antiserum to crystalline beef insulin.

\section{Reactions between insulin antisera and foreign proteins}

Experiments were designed to detect reactions between rabbit insulin antisera and any of the following proteins: egg albumin, human serum albumin, human gamma globulin, bovine serum albumin, and bovine gamma globulin (Table I).

The titration curve obtained when each of these proteins was preincubated with the insulin antiserum was very similar to that obtained when saline was preincubated with the same dilutions of antiserum. On the other hand, there was a marked inhibition of hemolysis of the insulin-conjugated erythrocytes by preincubation of crystalline insulin with the antiserum (Table I).

There was, therefore, no observable reaction be-

TABLE I

THE CROSSREACTIVITY OF RABBIT ANTI-INSULIN SERUM WITH PROTEINS OTHER THAN INSULIN.

\begin{tabular}{|c|c|c|c|c|c|}
\hline \multirow{3}{*}{$\begin{array}{l}\text { PROTEINS ( } 10 \text { p.) } \\
\text { PREIMCUBATED WITH } \\
\text { THE ANTISERUIM }\end{array}$} & \multicolumn{5}{|c|}{ DILUTIONS OF INSULIN ANTISERUM } \\
\hline & $1 / 75$ & $1 / 150$ & $1 / 300$ & $1 / 600$ & $1 / 200$ \\
\hline & \multicolumn{5}{|c|}{ PER CENT HEMOUYSIS OF INSULIN-ERYTHROCYTE } \\
\hline 0.1 mI SALLNE & 92 & 80 & 56 & 30 & 18 \\
\hline ECe ALBUMIN & 88 & 80 & 52 & 29 & 16 \\
\hline HUMAN SERUM ALB. & 87 & 78 & 51 & 22 & 17 \\
\hline HUMAN GAMMA GLOB. & 88 & 81 & 57 & 33 & 20 \\
\hline BOVINE SERUM ALB. & 87 & 84 & 57 & 33 & 20 \\
\hline BOVINE CAMMA GLO. & 92 & 88 & 60 & 36 & 20 \\
\hline INSULIN LOT" "S3SGEA & 19 & 18 & 14 & 11 & 10 \\
\hline
\end{tabular}


TABLE II

\begin{tabular}{|c|c|c|c|c|c|c|c|c|}
\hline \multicolumn{9}{|c|}{ 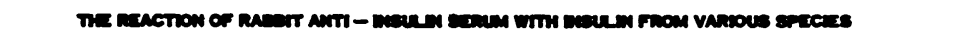 } \\
\hline \multirow{4}{*}{ 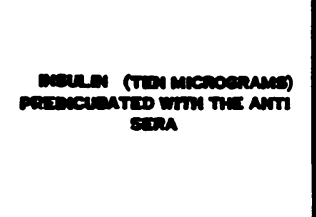 } & \multicolumn{4}{|c|}{ rascant } & \multicolumn{4}{|c|}{ nanolras } \\
\hline & \multicolumn{4}{|c|}{$\begin{array}{l}\text { NSUU WN CONLUEATED } \\
\text { HEEP ERYTHIOCVYTES }\end{array}$} & \multicolumn{4}{|c|}{ 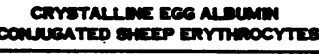 } \\
\hline & \multicolumn{4}{|c|}{ 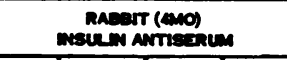 } & \multicolumn{4}{|c|}{$\begin{array}{l}\text { RABEAT 371 } \\
\text { ECG ALEvBW ANTISERLU }\end{array}$} \\
\hline & $\frac{1}{\pi}$ & $\frac{1}{100}$ & $\frac{1}{300}$ & $\frac{1}{\infty}$ & $\frac{1}{1000}$ & $\frac{1}{\infty \infty 00}$ & $\frac{1}{1000}$ & $\frac{1}{3000}$ \\
\hline 0.1 sauner & $\boldsymbol{n}$ & $\boldsymbol{\infty}$ & $\boldsymbol{n}$ & $\boldsymbol{\infty}$ & 100 & $\boldsymbol{n}$ & $\mathbf{2}$ & ? \\
\hline moven - Lot no. & 10 & 18 & 14 & 11 & 100 & $\boldsymbol{\omega}$ & $\mathbf{m}$ & 10 \\
\hline 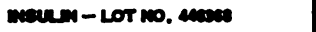 & 18 & $\boldsymbol{u}$ & 13 & 13 & 100 & $\boldsymbol{n}$ & $\mathbf{m}$ & - \\
\hline 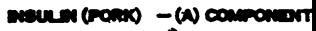 & 16 & 12 & 12 & 11 & 100 & 100 & 34 & - \\
\hline 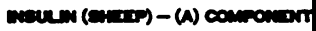 & 14 & is & 11 & 10 & 100 & $\boldsymbol{*}$ & $\omega$ & - \\
\hline 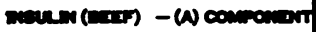 & 12 & 13 & $n$ & 12 & 100 & * & $\infty$ & 12 \\
\hline meven owsenas) & $\mathbf{2 a}$ & 22 & 14 & 12 & 100 & $\boldsymbol{*}$ & $\boldsymbol{\bullet}$ & $\mathbf{2 3}$ \\
\hline
\end{tabular}

tween the insulin antiserum and five proteins other than insulin, two of which were bovine in origin as was the insulin used to immunize the rabbits.

The cross-reactivity of rabbit insulin antiserum with highly purified samples of insulin from various species

Various insulin preparations were preincubated with rabbit insulin antisera before the addition of

CROSS REACTIONS OF RABBIT ANTI BEEF INSULIN SERUM (LILLY'S CRYSTALLINE ZINC) WITH SHEEP ERYTHROCYTES CONJUGATED WITH THE "A" COMPONENT OF INSULIN PREPARED BY COUNTER CURRENT DIFFUSION.

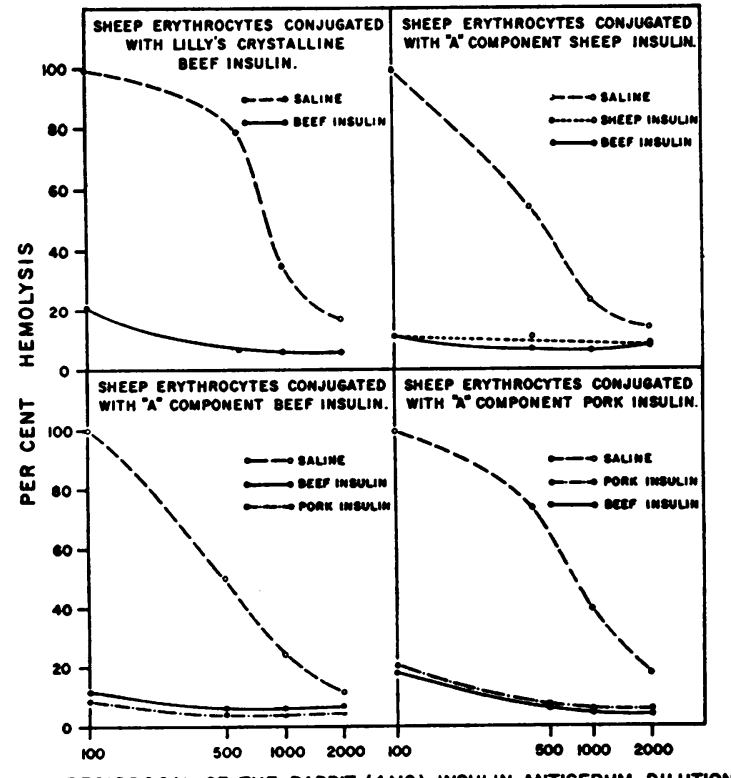

Figure 3 sheep erythrocytes conjugated with crystalline beef insulin. The degree of inhibition of hemolysis was very similar when any of the insulin samples from the various species was preincubated with the antiserum (Table II). The specificity of these reactions was checked by addition of the insulin samples to a control egg albumin-anti egg albumin system. In every case these additions did not inhibit the heterologous system.

Hemolysis of the insulin-conjugated red cells was inhibited to the same degree by preincubating the antiserum with $10 \mu \mathrm{g}$. of the following insulin samples: The highly purified " $A$ " components of beef, sheep, and pork insulin or crystalline beef and trypsinized beef insulin. When these samples were incubated with the $1 / 75$ dilution of the antiserum, 12 to 19 per cent hemolysis was observed. When saline was preincubated with the $1 / 75$ antiserum dilution 92 per cent hemolysis was observed (Table II). Human insulin also inhibited hemolysis when preincubated with insulin antiserum. More hemolysis (less inhibition) was observed with human insulin than with an equal amount of any of the other insulin samples. However, an increased hemolysis of egg albumin conjugated erythrocytes, greater than that seen with egg albumin antiserum dilutions preincubated with saline, also observed when human insulin was tested in the egg albumin system. This non-specific hemolysis of the erythrocytes may have been the result of the cresol present in the human insulin solution (Table II).

The extent to which insulin antisera hemolyzed 
erythrocytes conjugated with " $A$ " components of insulin was also tested (Figure 3). Cross-inhibition experiments, in which these " $A$ " components of sheep, pork, beef insulin, and crystalline beef insulin were preincubated with the insulin antiserum, were simultaneously performed. Figure 3 demonstrates the similarity of the hemolytic titration curves obtained when rabbit insulin antiserum was mixed with erythrocytes conjugated with " $A$ " components of sheep, pork, or beef insulin. The " $A$ " components of beef insulin inhibited the hemolysis of cells conjugated with sheep, pork, or beef insulin. The " $\mathrm{A}$ " component of sheep insulin inhibited the hemolysis of red conjugated with sheep insulin. The " $A$ " component of pork insulin inhibited the hemolysis of cells conjugated with beef and pork insulin. Thus, it is apparent that rabbit antiserum against crystalline beef insulin cross-reacts to a high degree with the " $A$ " components of sheep, pork, and beef insulin.

\section{The neutralization of insulin by rabbit insulin antisera in the mouse}

Insulin may be measured and characterized by its physiological action, i.e., the lowering of blood sugar and the subsequent production of insulin shock. In the characterization of any insulin anti- serum it is, therefore, desirable to demonstrate the in vivo neutralization of insulin by the antiserum.

Solutions of rabbit insulin antiserum incubated with insulin at room temperature prolonged the length of time mice could maintain their body weight on an inclined screen as compared with solutions of normal rabbit serum incubated with insulin under the same conditions (Figure 4).

Insulin was mixed with normal rabbit serum or antiserum not less than five minutes or longer than 15 minutes before these solutions were injected intraperitoneally into mice. Ninety-eight experimental mice were injected with the mixture of antiserum and insulin and forty-nine control mice were injected with the mixture of normal rabbit serum and insulin. The mice injected with a mixture of antiserum and insulin remained clinging to the screen significantly $(p-0.0004)$ longer than the mice injected with the mixture of normal rabbit serum and insulin.

Mice which were injected with a mixture of insulin and normal rabbit serum which had incubated at room temperature longer than 15 minutes were able to hang on to the screen significantly $(p-$ 0.04) longer than those mice which were injected with a mixture of insulin and antiserum which had been incubated a comparable length of time (Figure 5).

\section{INSULIN ANTISERUM PROTECTION AGAINST INSULIN}

IN THE MOUSE.

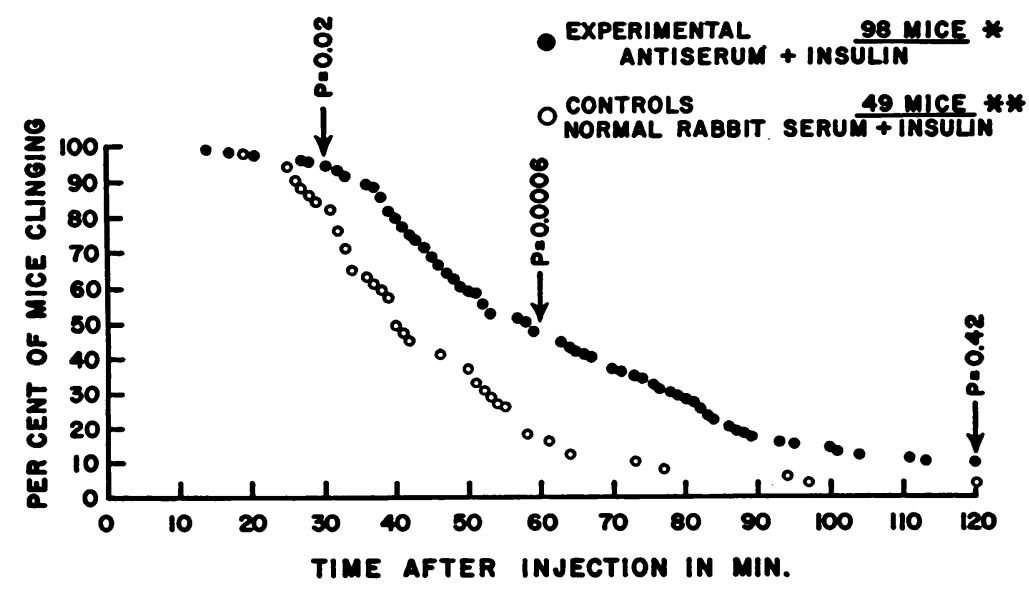

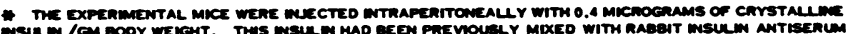

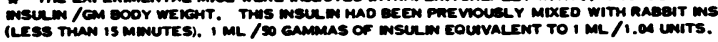

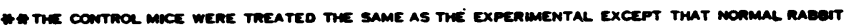




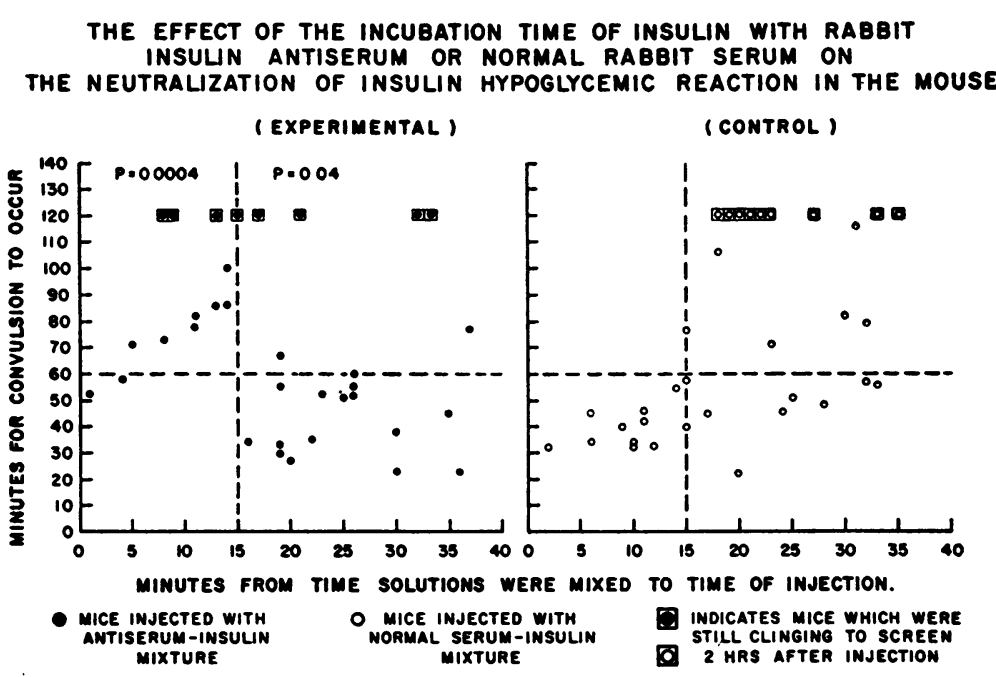

Figure 5

\section{DISCUSSION}

Using the hemolytic titration of rabbit insulin antiserum, as described in the previous paper (2), evidence has been obtained that the rabbit antisera to insulin are highly specific for insulin: 1) There was no observable reaction with foreign proteins. 2) There was little if any reaction with antigens from bovine serum or bovine pancreas. 3) The antisera reacted quantitatively with only the insulin in a crude extract of pancreas. 4) The insulin-induced hypoglycemic reaction was delayed by the rabbit insulin antisera in the mouse.

The hemolytic method was used to test the specificity of these antisera since it is the method which is proposed for the assay of insulin. It is not known whether these rabbit antisera to insulin would have reacted so specifically had other immunological or serological techniques been employed in testing their specificity.

Lewis (3), Wasserman and Mirsky (5), and Moloney and Coval (9) using different techniques were able to demonstrate the immunological similarity of insulin from various species. In the present study there was a great degree of crossreaction between the rabbit antisera to crystalline beef insulin and the highly purified " $A$ " components of sheep, beef and pork insulin. However, these results do not mean that insulins from various species are identical. These results are in accord with the finding by Sanger (17) that insulin preparations from ox, sheep and pork are very similar but not identical in amino acid composition.

Whether these antisera will react with the endogenous insulin in the various species tested is difficult to predict. There does not seem to be any indication that the antibodies produced by the rabbit in any way reacted with the endogenous insulin of the rabbit. Repeated glucose tolerances and periodic blood glucose determinations of the rabbits in various phases of immunization were consistently normal. This has also been observed by Moloney and Coval (9) in sheep and guinea pigs. Moloney and Coval have also presented evidence (9) that guinea pig antisera to crystalline pork insulin will react with "altered" pork, sheep, ox, rabbit and guinea pig insulin. These antisera also react with endogenous mouse insulin but not with endogenous guinea pig insulin.

It is possible, therefore, that endogenous insulin may be species specific and that in the course of purification this species specificity is lost. This would have significant bearing on the application of the immunological assay of insulin and is currently being investigated.

The neutralization of insulin by immune sera has been reported previously (6-9). However, in the present study the antiserum delayed the hypoglycemic action of insulin only when mixed with insulin for less than fifteen minutes. Under these conditions, the immune serum neutralized insulin rapidly compared to normal rabbit serum. 
Mice injected with solutions of normal rabbit serum and insulin mixed longer than 15 minutes clung to the screen longer than those mice which which were injected with solutions of immune rabbit serum and insulin which had been incubated longer than 15 minutes. Mice injected with solutions of insulin and normal rabbit serum incubated longer than 15 minutes clung to the screen longer than mice injected with the same solutions which were incubated less than 15 minutes. Therefore, normal serum alone delayed the hypoglycemic action of insulin when mixed with insulin longer than 15 minutes at room temperature. This delayed inhibition of insulin was not observed when the immune serum was incubated with the insulin at room temperature longer than 15 minutes.

Explanation of the transitory nature of the neutralization of the immune serum on insulin by dissociation of the antibody antigen complex is presently without basis since no evidence of dissociation was noted in vitro by the hemagglutination or hemolytic methods.

The action of the normal rabbit serum (heated at $56^{\circ} \mathrm{C}$ for 30 minutes) on insulin is also difficult to explain; whether the insulin is destroyed or neutralized in some way by the normal rabbit serum is unknown.

The transitory neutralization of insulin by rabbit antiserum and the effect of normal rabbit serum on insulin have not been previously described. Therefore, it is not known to what extent these phenomena apply to the sera of other species, especially man. Certainly, if they apply to human sera, failure to take them into consideration might lead to erroneous conclusions.

On the basis of these observations, the hemolytic method employing rabbit antiserum to insulin appears to be specific and sensitive enough for the assay of insulin in biological fluids and tissues. This application is, therefore, being currently investigated.

\section{SUMMARY}

1. As tested by the immune hemolysis method, rabbit antisera to alum precipitated crystalline bovine insulin were highly specific for insulin.

2. These antisera cross-reacted to very marked degree with trypsinized beef insulin, human in- sulin, and the " $A$ " components of sheep, pork and beef insulin.

3. As compared with normal rabbit serum, the rabbit insulin antisera significantly delayed the hypoglycemic action of insulin only when mixed with insulin for less than 15 minutes. Normal serum alone delayed the hypoglycemic action of insulin when mixed with insulin longer than 15 minutes.

4. In view of the evidence presented the application of these antisera to the assay of insulin in mixtures of proteins was suggested.

\section{ACKNOWLEDGMENTS}

The authors are very appreciative of the competent technical assistance of Eleanor Allen. They are also grateful to Dr. Arnold Lazarow for many stimulating comments in the course of these studies.

\section{REFERENCES}

1. Arquilla, E. R., and Stavitsky, A. B., Evidence for the specificity of rabbit anti-insulin serum. Anat. Rec., 1955, 121, 256.

2. Arquilla, E. R., and Stavitsky, A. B., The production and identification of antibodies to insulin and their use in assaying insulin. J. Clin. Invest., 1956, 35, 458.

3. Lewis, J. H., The antigenic properties of insulin. J.A.M.A., 1937, 108, 1336.

4. Barral, P., and Roux, J., L'insulin constitue-t-elle en elle-même un antigène spécifique? Compt. rend. soc. de biol., 1931, 106, 292.

5. Wasserman, P., and Mirsky, I. A., Immunological identity of insulin from various species. Endocrinology, 1942, 31, 115.

6. Lowell, F. C., Immunologic studies in insulin resistance. III. Measurement of an insulin antagonist in the serum of an insulin-resistant patient by the blood sugar curve method in mice. J. Clin. Invest., 1947, 26, 57.

7. Banting, F. G., Franks, W. R., and Gairns, S., Physiological studies in metrazole shock. VII. Antiinsulin activity of insulin-treated patient. Am. J. Psychiat., 1938, 95, 562.

8. Marsh, J. B., and Haugaard, N., The effect of serum from insulin-resistant cases on the combination of insulin with rat diaphragm. J. Clin. Invest., 1952, 31, 107.

9. Moloney, P. J., and Coval, M., Antigenicity of insulin : Diabetes induced by specific antibodies. Biochem. J., 1955, 59, 179.

10. Harfenist, E. J., and Craig, L. C., Countercurrent distribution studies with insulin. J. Am. Chem. Soc., 1952, 74, 3083. 
11. Oncley, J. L., Melin, M., Richert, D. A., Cameron, J. W., and Gross, P. M., The separation of antibodies, isoagglutinins, prothrombin, plasminogen, and $\beta_{1}$ lipoproteins into subfractions of human plasma. J. Am. Chem. Soc., 1949, 71, 541.

12. Cohn, E. J., Strong, L. E., Hughes, W. L., Jr., Mulford, D. J., Ashworth, J. N., Melin, M., and Taylor, J., Preparation and properties of serum and plasma proteins. VI. A system for the separation into fractions of the protein and lipoprotein components of biological tissues and fluids. J. Am. Chem. Soc., 1946, 68, 459.

13. Stavitsky, A. B., Micromethods for the study of proteins and antibodies. I. Procedure and general applications of hemagglutinations and hemagglutination-inhibition reactions with tannic acid and protein-treated red blood cells. J. Immunol., 1954, $72,360$.

14. Brumfield, H. P., and Ross, J. D., A sheep erythrocyte lysin found in guinea pig serum. J. Immunol., 1954, 72, 489.

15. Pillemer, L., Blum, L., Lepow, I., Ross, O. A., Todd, E. W., and Wardlaw, A. C., The properdin system and immunity. I. Demonstration and isolation of a new serum protein, properdin, and its role in immune phenomena. Science, 1954, 120, 279.

16. Snedecor, G. W., Statistical Methods, 4th ed., Ames, Iowa. The Iowa State College Press, 1946.

17. Sanger, F., Species differences in insulins. Nature, 1949, 164, 529. 